\section{MRS Council Approves Headquarters Building}

Anybody who has visited our Materials Research Society headquarters in Pittsburgh knows that we have outgrown our current leased space. Early last year, Carl Thompson, then president of MRS, chartered a task force consisting of councillors Merrilea Mayo, Charlie Duke, and me to work with John Ballance, executive director of MRS, and begin the process of looking for more appropriate rental space. During that search, we were also asked by the MRS Executive Committee to investigate the option of building a new headquarters. After many months of investigation, our analysis showed that the most cost-effective, long-term solution was in fact for us to construct our own building.

In the Fall of 1996, we contracted with a construction project manager and architect to determine a design and budget for the project. The first step in that process was establishing the building requirements. The programming team actively solicited input from the headquarters staff to define the building needs. In addition, a group of Society officers and councillors that sometimes conduct business at headquarters was also formed to provide input. Many thanks to Carl Thompson, John Bravman, Bob Nemanich, and Robert Hull for working with Merrilea Mayo on that team. By late October, we had reached a consensus on the requirements for a headquarters facility that we felt would serve us well into the next century. Special consideration was given to make the facility electronic communication friendly.

By the time of the 1996 MRS Fall Meeting/ICEM-96, we had found an ideal site for the building. It is in a commercial park near the present headquarters. The Minerals, Metals \& Materials Society and near the current leased office.

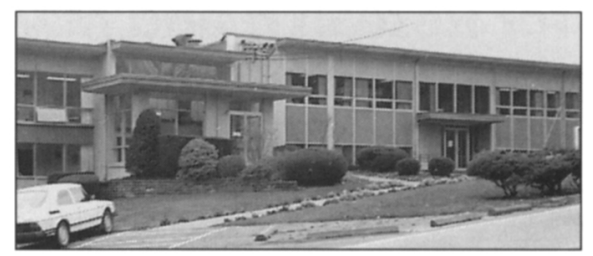

Current Materials Research Society headquarters are leased from the first and third floors of this office building on 9800 McKnight Road in Pittsburgh,

Pennsylvania. the Society of Automotive Engineers headquarters are presently located in the park. In addition, we were ready to go to Council with a detailed floorplan, artist's concept, and detailed project budget. Council approved the project at the meeting, and we are ready to proceed with the financing and construction.

If all goes well, the staff at headquarters and the volunteers who occasionally use the facility will be in the new headquarters by early Fall of 1997.

ALAN TAUB

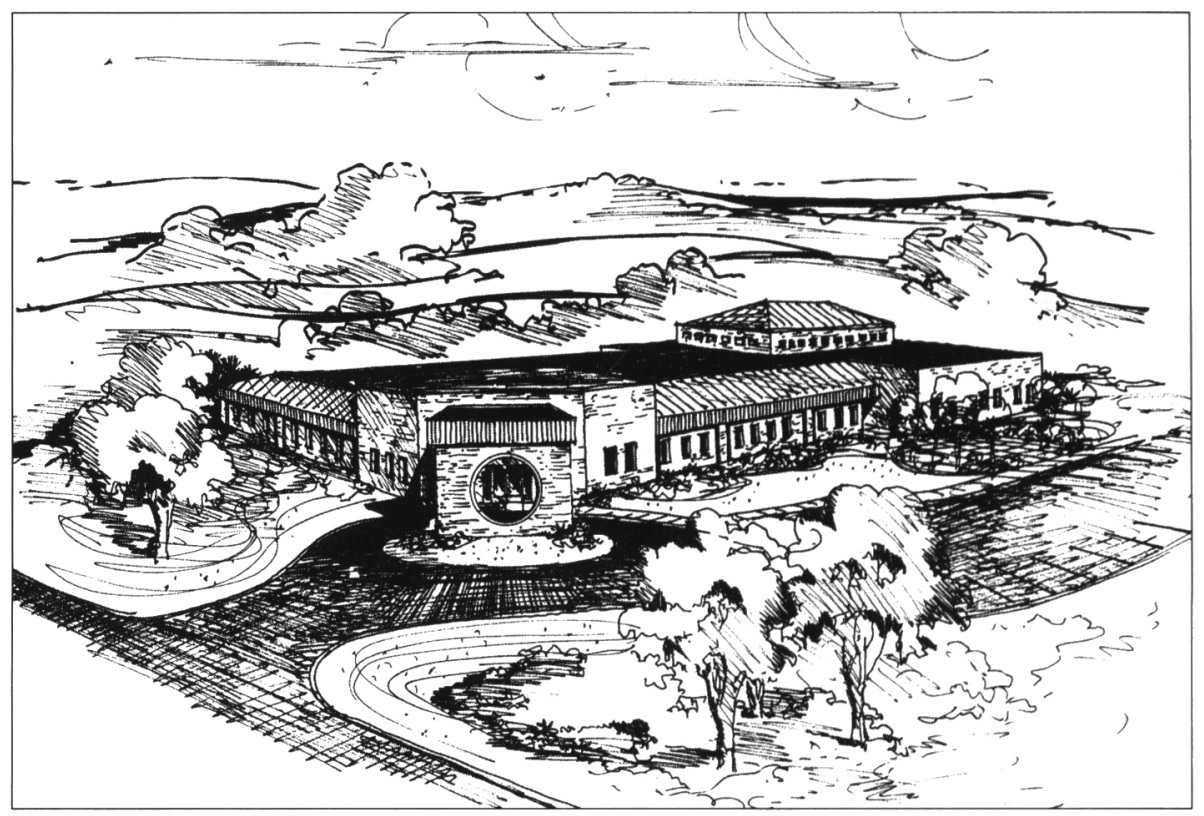

Artist's concept of the Materials Research Society headquarters building to be constructed during the summer of 1997 in Thorn Hill Industrial Park outside Pittsburgh, Pennsylvania, 